\title{
Milestones and Directions: Socio-Legal Studies in Germany and the United Kingdom
}

\author{
Stefan Machura* ${ }^{(1)}$ \\ (Received 07 September 2020; accepted 13 September 2020)
}

\begin{abstract}
Under the headings of "Rechtssoziologie" in Germany and "socio-legal studies" in the UK, scholarly traditions have developed that relate law to its social environment. This Article identifies key stages in the development the subject took in both countries and the directions of travel. Comparable milestones were passed, and directions were taken in Germany and the UK. This includes the institutionalization of the subject along the lines of programmatic texts; becoming part of university education; and the establishment of research institutes, academic associations, and specialized journals. The development tells us something beyond sociology of law or socio-legal studies, namely about the relation of law and sociology, the parent disciplines themselves, as well as about academic studies and professional and institutional practice. However, in contrast to the UK, there is still more of a distance between the sociology of law and jurisprudence in Germany.
\end{abstract}

Keywords: Sociology of law; socio-legal studies; Socio-Legal Studies Association; empirical legal research; legal education

\section{A. Introduction: What is "Socio-Legal Studies" or "Sociology of Law"?}

Considering how "sociology of law," or "socio-legal studies," developed in Germany and the UK, this Article analyzes the institutionalization of the subject. How did it grow roots in the two countries? As other contributions to the workshop and this Special Issue explicitly focus on the trajectory of theoretical thought in socio-legal studies, this Article will only note those aspects in passing. ${ }^{1}$ Interest in sociology of law, or socio-legal studies, started to develop mainly in the twentieth century and took similar trajectories in Germany and the UK. Though the UK lagged

\footnotetext{
${ }^{*}$ Stefan Machura is a Professor of Criminology and Criminal Justice at Bangor University. Professor Machura received his first $\mathrm{PhD}$ dealing with the control of state-owned enterprises from Ruhr University Bochum. He went on to earn his second $\mathrm{PhD}$ (Habilitation in public management) from Bundeswehr University Munich. In 2005, he did an Umhabilitation for political science from the Ruhr-Universität Bochum. Since 2000, Professor Machura has been an editor of the Zeitschrift für Rechtssoziologie. The German Journal of Law and Society. This Article has been presented at the workshop "Socio-Legal Studies in Germany and the UK: Theory and Methods," organized by the Socio-Legal Studies Association and the Law \& Society Institute (LSI), Faculty of Law, Humboldt University Berlin, September 23-24, 2019 in Berlin. Professor Machura wishes to thank Jen Hendry and Naomi Creutzfeldt for their many suggestions.

${ }^{1}$ The author has elsewhere narrated the history of sociology of law in Germany in more detail in Stefan Machura, The German Sociology of Law: A Case of Path Dependency, 8 INT'L J.L. ConTEXT 506 (2012), covering the development of the two parent disciplines as well as political and social movements inspiring some of the actors. For alternative accounts on sociology of law in Germany see, for example, Michael Wrase, Rechtssoziologie und Law and Society - Die deutsche Rechtssoziologie zwischen Krise und Neuaufbruch, 27 ZFRSoz 289 (2006); Alfons Bora, Sociology of Law in Germany: Reflection and Practice, 43 J.L. Soc'y 619 (2016).

(C) The Author(s), 2020. Published by Cambridge University Press on behalf of the German Law Journal. This is an Open Access article, distributed under the terms of the Creative Commons Attribution-NonCommercial-NoDerivatives licence (http://creativecommons.org/ licenses/by-nc-nd/4.0/), which permits non-commercial re-use, distribution, and reproduction in any medium, provided the original work is unaltered and is properly cited. The written permission of Cambridge University Press must be obtained for commercial re-use or in order to create a derivative work.
} 
behind for a long time, it caught up quickly over the last decades. Today, the subject may have an even larger base in the British Isles than in Germany. This was helped by a wider definition of the study area in the UK than in Germany, a greater openness towards inter- and transdisciplinary work in the UK, more flexibility of teaching demonstrated by faculties, and supported by more wide-spread employment opportunities.

What defines sociology of law? A key German player, Erhard Blankenburg, has described it as a social science "dealing with legal institutions and law-oriented behavior, striving to explain these from the canon of sociological theories and which simultaneously disciplines itself to methodological standards consented among social scientists." 2 The main contrast here is between social science and dogmatic law, where the latter is the study of law as found in authoritative legal texts with an aim to prepare, or at least to contemplate, legal decisions. Comparatively, sociology of law takes legal doctrine or legal decisions as "data," and jurisprudence employs aspects of sociological theory or sociological methods not only to theorize law but also to inform decision-making. The latter largely describes the socio-legal studies beyond sociology of law. Socio-legal studies must be the broader term, while sociology of law is somewhat more specific. The former could be perceived as identical with the "law and society" label, reflecting a broad range of topics, paradigms, and methods on display at the annual meetings of the United States' Law and Society Association (LSA). ${ }^{3}$

What in Germany is called "Rechtstatsachenforschung" takes little reference to sociological concepts. But, as an "empirical study of law," it draws purely on social science research methods to inquire into problems of the application of law. The conflict between this type of socio-legal studies and sociology of law, concerned with understanding the function of law in society, was prominent in the twentieth century among academics in the UK. The divide was not as important in other parts of Europe. ${ }^{4}$ Indeed, there can be a fruitful division of labor between the two. ${ }^{5}$ The study of law as part of society can only benefit from an inter- and transdisciplinary approach, ${ }^{6}$ in which content from different academic disciplines is combined.

A plethora of neighboring social science and humanities subjects are drawn into socio-legal studies and sociology of law. The most successful being criminology, which experienced a phenomenal rise in public awareness, student numbers, degree courses, and targeted academic research in the UK. "Gradually the subject took off during the 1980s as crime and crime control became defined as a more central socio-political problem in the UK and police procedurals became a central part of television (now media streaming) culture." 7 In the UK, criminology is based in law schools at some universities and social sciences at other places. There are several permanent lectureships at one university. German criminology is almost exclusively at home at law schools where there is typically only one criminology professor with secure employment. Criminology in Germany has long been part of the study of law, with sociological and psychological content increasingly defining the subject, following the American example.

Historically strong relations exist between sociologists of law in the three German-speaking countries of Austria, Germany, and Switzerland. In equal measure, British academia is well connected to Australia, New Zealand, and other Commonwealth countries, or erstwhile British

\footnotetext{
${ }^{2}$ Erhard Blankenburg, Die Praxisrelevanz einer Nicht-Disziplin: der Fall der Rechtssoziologie, in SozIOLOGIE UND PRAXIS. Soziale Welt, (Special Issue) 205, 206 (Ulrich Beck ed., 1982) (author's own translation).

${ }^{3}$ Its website lists no less than fifty-six Collaborative Research Networks, formed around joint scholarly interests, organizing the bulk of the activities. LAW AND SOCIETY Association, https://www.lawandsociety.org/ (last visited 26 April 2020).

${ }^{4}$ David Nelken, The 'Gap Problem' in the Sociology of Law: A Theoretical Review, 1 WINDSOR Y.B. AcCEss JUST. 35 (1981), reprinted in BEYOND LAW IN CONTEXT 1, 2 (2009).

${ }^{5} I d$. at $7-8$.

${ }^{6}$ Alfons Bora, Armin Höland, Dorothea Jansen, Doris Lucke, Stefan Machura, Wolfgang Ludwig-Mayerhofer \& Gunther Teubner, Rechtssoziologie „auf der Grenze“: Mitteilung der Herausgeber, 21 ZFRSoz 319 (2000).

${ }^{7}$ Mike Levi, Emerged from the American Shadows? Reflections on the Growth of Criminology in the UK, 16 CRIM. EUR. 4, 5 (2017).
} 
colonies. Ideas and staff sometimes travel lightly between the English-speaking nations and between the German-speaking countries. German sociologists of law closely follow English language literature, but few colleagues in the UK are able to read publications in German. Communication flows, therefore, tend to be slightly one-sided. When it comes to the structural development of sociology of law and socio-legal studies, the conditions within the two countries were key, as will be shown in the remainder of this Article.

\section{B. The Early Mobilization Phase of Sociology of Law}

\section{Beginnings in Germany}

The field developed much earlier in Germany than in the UK. Established academics pioneered sociology of law by the turn of the nineteenth to the twentieth century. This was the generation of Eugen Ehrlich, as well as Max and Marianne Weber. Ehrlich published his famous book Grundlegung der Soziologie des Rechts in 1913. His basic idea was that there is "dead law" that exists in the legal codes but is not being applied in practice, and there is "living law," some of which bears no relation to the state's written law. ${ }^{8}$ Associations within society may organize themselves along self-developed rules. For example, if judges are called to decide in a dispute, they need to be trained to find out about those non-state but essential rules. Sociology of law would equip lawyers to research the non-codified "living law" through observation, interviews, or the study of legal documents. In this way, sociology of law becomes part and parcel of a more encompassing legal science. Ehrlich's ideas met considerable support, but also strong resistance. It started with the Kelsen-Ehrlich debate. ${ }^{9}$ Ehrlich was not particularly extreme in his views, but he was often carried away by his rhetoric. Politically of liberal-conservative persuasion, his "revolution" meant providing lawyers with an additional empirical method to understand law. He did not aim to do away with state law or with legal training based on legal texts. Hans Kelsen, his adversary, pointed out logical errors in Ehrlich's argumentation, but he did not deny sociology of law a place within jurisprudence.

Max Weber's sociology of law, published after his death, emphasized the technical advantages of the modern dogmatic law based on the systematizing work undertaken by lawyers. ${ }^{10}$ This type of law serves a capitalist economy and a liberal society. In his analysis, Weber was not at all blind to the problem of economic power turning into advantages for specific classes of people when dealing with the law and when developing the law. As a liberal thinker, he saw the alternatives as essentially worse, even for those disadvantaged by the modern legal regime.

Sociologists of law were quite prominent on the academic scene when German sociology took the first steps towards institutionalization at the beginning of the twentieth century. Max Weber was heavily involved in founding the Deutsche Gesellschaft für Soziologie in 1909. ${ }^{11}$ Nevertheless, the political, economic, and intellectual climate proved unfavorable, and the catastrophic twelve years of national socialist rule largely stopped German sociology in its tracks. In the divided postwar Germany, sociology of law started slowly in the Federal Republic and saw an accelerated development in the 1970s and 1980s. Comparatively, in the German Democratic Republic (GDR), the leadership of the ruling Socialist Unity Party did not allow any initiative in the direction of sociology of law to become a reality. The subject was seen as incompatible with the

\footnotetext{
${ }^{8}$ Eugen Ehrlich, Das lebende Recht der Völker der Bukowina, in EUGEN EHRLICH, RECHT UND LEBEN 43 (Manfred Rehbinder ed., 1967) (1912); Eugen Ehrlich, Grundlegung Der Soziologie DEs Rechts (4th ed., 1989); Eugen Ehrlich, Über das "lebende Recht," in POLITISCHE SCHRIFTEN 191 (Manfred Rehbinder ed., 2007).

${ }^{9}$ Hans Kelsen, Eine Grundlegung der Rechtssoziologie, in ReCHTSSOZIOLOGIE UND ReCHTSWISSENSCHAFt 3 (reprt. Klaus Lüderssen ed., 2003) (1915); Stefan Machura, Eugen Ehrlich's Legacy in Contemporary German Sociology of Law, in Eugen Ehrlich's Sociology of LaW 39 (Knut Papendorf, Stefan Machura \& Anne Hellum eds., 2014).

${ }^{10}$ Max Weber, Wirtschaft und Gesellschaft (Johannes Winckelmann ed., 5th ed. 1980).

${ }^{11}$ Marianne Weber, MaX Weber: Ein Lebensbild 425-430 (4th ed. 1989); Uwe Dörk, Sonja Schnitzler \& Alexander Wierzock, Die Gründung der deutschen Gesellschaft für Soziologie vor 110 Jahren, 48 SozIOLOGIE 309, 311-13 (2019).
} 
prevailing Marxist-Leninist ideology. Once the working class established its own rule, there would be no need for sociology of law. ${ }^{12}$ In the process of German reunification after 1990, the legal structures, institutions, and personnel of the West were introduced.

In the early years of West Germany, aspects of sociology of law were part of lectures in philosophy of law. ${ }^{13}$ A key step forward proved the editing of Weber's sociology of law by Johannes Winckelmann in 1956 as part of the Economy and Society compilation of Weber's texts. The subject now had an authoritative text that was less controversial than Ehrlich's 1913 book, Grundlegung einer Soziologie des Rechts. The 1960s saw a further build-up of sociology of law. In 1964, the first institute for sociology of law was founded by Ernst E. Hirsch at the Free University Berlin. ${ }^{14}$ Still, students of sociology of law lacked a textbook in the German language. Finally, in 1967, Hirsch and Manfred Rehbinder edited a widely used textbook, which also introduced American work to German readers. ${ }^{15}$ The wider public may have learned about sociological inquiries on law through opinion research. Elisabeth Noelle-Neumann acquainted Germans with opinion research, ${ }^{16}$ a field that developed in the United States. Some of her surveys touched on legal topics. ${ }^{17}$ Sociology of law gained prominence through a series of empirical studies concerning law students, lawyers, and judges. Ralf Dahrendorf emphasized the dominance of representatives from the higher social stratum in law. The upper half of society would sit in judgment over the lower half. ${ }^{18}$ Marxists went a step further and referred to Ernst Fraenkel's attack on "class justice" from the Weimar years, which by then the author himself had already come to see as too extreme a view. ${ }^{19}$ An alternative theory was put forward by Judge Theo Rasehorn. ${ }^{20}$ This was essentially a socialization theory: The bureaucratic apparatus of the justice system forms the actions of legal personnel. Rasehorn's theory was later supported by further empirical studies. ${ }^{21}$ Both approaches, the class and the bureaucratic perspective, were quite unflattering for the legal profession and, as they were also written in forceful language, created quite a stir.

Interest in sociology of law continued to grow, and at the end of the decade, students demanded that the subject be taught, which meant an institutionalization of the subject had to be granted. In the feverish atmosphere of the "student revolution," starting in 1967, some activists saw sociology of law as an opener for the introduction of Marxist doctrine into universities. Others favored "sociological jurisprudence," the phrase, of course, being much earlier used by Roscoe Pound for drawing on "the relations of law to society." 22 The students' demand was chiming in with the zeitgeist of the period, which widely believed in social engineering. The books Sociology Before the Gates of Jurisprudence and Jurisprudence as Social

\footnotetext{
${ }^{12}$ Rosemarie Will, Betrifft: Forschungsprofilierung Rechtssoziologie, 11 ZFRSOZ 2 (1990).

${ }^{13}$ Theo Rasehorn, Wolfgang Kaupen und die deutsche Rechtssoziologie. Aufstieg und Niedergang, in EMPIRISCHE Rechtssoziologie. Gedenkschrift für Wolfgang Kaupen 15, 15-16 (Dieter Strempel \& Theo Rasehorn eds., 2002).

${ }^{14}$ Thomas Raiser, Keynote Address: Sociology of Law in Germany, 11 German L.J. 391, 392 (2010).

${ }^{15}$ ERnst. E. Hirsch \& MANFred ReHbinder, Studien und Materialien zur Rechtssoziologie, in KZFSS, SONDERHEFT, No. 11 (Ernst. E. Hirsch \& Manfred Rehbinder eds., 2d ed. 1971).

${ }^{16}$ David Childs, Elisabeth Noelle Neumann: Pioneer of Public-Opinion Polling and Market Research, INDEPENDENT (Apr. 10 , 2010) www.independent.co.uk/news/obituaries/elisabeth-noelle-neumann-pioneer-of-public-opinion-polling-and-marketresearch-1940766.html.

${ }^{17}$ See, e.g., Elisabeth Noelle-Neumann, Rechtsbewußtsein im wiedervereinigten Deutschland, 16 ZFRSOZ 121 (1995).

${ }^{18}$ Ralf Dahrendorf, Gesellschaft und Freiheit 195 (1963).

${ }^{19}$ Ernst Fraenkel, Zur Soziologie der Klassenjustiz und Aufsätze ZUr Verfassungskrise 1931-32 (1968).

${ }^{20}$ Written under pseudonym Xaver BerRa, IM PARAgraphenturm: EINE STREITSCHRIFT ZUR ENTIDEOLOGISIERUNG DER Justiz (1966).

${ }^{21}$ Rüdiger Lautmann, Rechtsfindung als Karriereberuf, in FESTSCHRIFT FÜR RUDOLF WASSERMANN ZUM SECHZIGSTEN

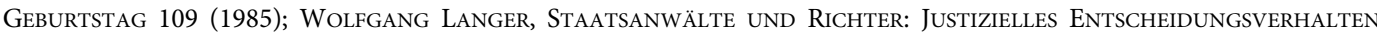
ZWISCHEN SACHZWANG UND LOKALER JUSTIZKUltur 66 (1994).

${ }^{22}$ A. Javier Treviño, Pound, Roscoe (1870-1964), in EncyClopedia of LAW AND Society: AmERICAN AND GLOBAL Perspectives 1160, 1161 (David S. Clark ed., 2007). See Roscoe Pound, The Scope and Purpose of Sociological Jurisprudence, 24 HARV. L. REV. 489, § III. Sociological Jurisprudence (1911).
} 
Science alerted legal academia. ${ }^{23}$ As much as these debates helped the initial institutionalization of sociology of law, they also triggered fierce resistance from traditionally-minded law professors. The reaction of many was, "don't rock the boat." There was little appetite on the part of many legal scholars to transform jurisprudence for various reasons, including the limited practicability of sociological jurisprudence, which can be too cumbersome when decisions have to be made quickly. ${ }^{24}$ Still today, German legal education somewhat neglects the training needs of law graduates aiming for a career in politics and administration where social science knowledge is obviously beneficial. The influential sociologist Helmut Schelsky first supported the institutionalization of sociology of law, but he started to fiercely and loudly criticize left-leaning reformers. ${ }^{25}$ The short period of change was quickly followed by the onset of a roll-back. The efforts of lawyers wanting to defend the traditional outlook of jurisprudence, a disappointment in society and politics about the practicality of social engineering on a large scale-as well as the onset of repeated economic crises with the ensuing austerity measures, all came together to endanger the institutionalization of sociology of law.

\section{Beginnings in the UK}

In the United Kingdom, sociology developed much later than in Germany. It essentially began in the 1960s. ${ }^{26}$ Richard Münch paints a particular trajectory for British sociology as it was "developed in correspondence with the labor movement. As such, social theory portrayed society as a class hierarchy and societal development that was shaped by class conflict and power." ${ }^{27}$ Other authors, outlining the history of socio-legal studies and sociology of law in the UK, emphasize a very long tradition of empirical and reform-oriented research, but with a noted absence, if not adversity, towards general social theory in Britain. ${ }^{28}$

The earliest events relevant to the present discussion included "law in context" studies in the new universities of Kent and Warwick, according to Bradney, on government initiative. ${ }^{29}$ Warwick kept all the law in context teaching in-house within the Law School and integrated it into the teaching of law subjects, whereas Kent drew on teaching provisions from other academic subjects. ${ }^{30}$ Sociology of law was just an optional third-year module in Warwick at that time. ${ }^{31}$ In retrospect, Foster and Osborn argue that "contextualism" did not take full advantage of what interdisciplinarity can offer and kept centered on understanding the operation of law. ${ }^{32}$

\footnotetext{
${ }^{23}$ Rüdiger Lautmann, Soziologie vor den Toren der Jurisprudenz (1971); Helmut Rottleuthner, Rechtswissenschaft als Sozialwissenschaft (1973); Doris Lucke, Feminae ante portas: Gleichstellung und Geschlechtergerechtigkeit in der Jurisprudenz, 39 ZFRSOZ 298, 309 (2019) (commenting on the effect most recently).

${ }^{24}$ Practical problems of sociological jurisprudence are outlined by KLAUS F. RÖHL, RECHTSSOZIOLOGIE 100-01 (1987) [hereinafter RöHl, RechtssozIologie]; Klaus F. Röhl, Zur Bedeutung der Rechtssoziologie für das Zivilrecht, in ReCHTSSOZIOLOGIE AM Ende des 20. Jahrhunderts: Gedächtnissymposium für Edgar Michael WenZ 39, 51 (Horst Dreier ed., 2000).

${ }^{25}$ Helmut Schelsky, Die Arbeit tun die anderen: Klassenkampf und Priesterherrschaft der Intellektuellen (2d ed. 1975).

${ }^{26}$ Max Travers, Sociology of Law in Britain, 32 Am. Sociologist 26, 28 (2001); Michael Albrow, The Changing British Role in European Sociology, in Sociology IN Europe: In SEARCH OF AN IDENTITy 81, 85 (Brigitta Nedelmann \& Piotr Sztompka eds., 1993).

${ }^{27}$ Richard Münch, The Contribution of German Social Theory to European Sociology, in Sociology IN EUROPE: IN SEARCH OF AN IDENTity 45, 47 (Brigitta Nedelmann \& Piotr Sztompka eds., 1993).

${ }^{28}$ Carl Campbell \& Paul Wiles, The Study of Law in Society in Britain, 10 L. \& Soc'Y Rev. 551, 555-56 (1976).

${ }^{29}$ Anthony Bradney, United Kingdom, in ENCYClopedia of LAw AND Society: American and Global Perspectives 1529, 1529 (David S. Clark ed., 2007).

${ }^{30}$ Ralph Folsom \& Neil Roberts, The Warwick Story: Being Led Down the Contextual Path of the Law, 30 J. LEGAL EDUC. 166, 182-83 (1979).

${ }^{31} I d$. at 176 .

${ }^{32}$ Ken Foster \& Guy Osborn, Dancing on the Edge of Disciplines: Law and the Interdisciplinary Turn, 8 ENT. \& SPORTS L.J. 4 , 4-5 (2010).
} 
A 1971 Parliamentary report on legal education, the "Ormrod Report," called for universities to "impart an understanding of the relationship of law to the social and economic environment in which it operates and the intellectual training necessary to enable students to handle facts and apply abstract concepts to them."33 Pat Carlen mentions the Social Science Research Council, the principal state funding agency — today, the Economic and Social Research Council (ESRC) setting up a socio-legal committee in $1972 .{ }^{34}$ It was formed at about the same time as a socio-legal group within the Society for Public Teachers of Law. ${ }^{35}$ According to Folsom and Roberts, there was a demand for social sciences and humanities coming from the substantial part of law students who did not wish to gain a professional legal qualification. ${ }^{36}$ Both U.S. lecturers and those teaching abroad influenced the direction taken by Warwick and elsewhere. ${ }^{37}$ As in Germany, the subject gained momentum when a younger generation of scholars, inspired by Marxism, started to study theories on law and society. ${ }^{38}$ Meanwhile, there was also an established pattern of pragmatist research directed at reforming the public sector and the welfare state, which encompassed the state of affairs in the legal system. ${ }^{39}$ As Michael King put it, "many of us believed that the social sciences held the key that would unlock the door to universal knowledge on how best to control people's behavior and regulate social life for the benefit of all society's members." ${ }^{20}$ Early discussions focused on the contrast between the two camps: Theorists, most notably of the Marxist persuasion, and empirical researchers. ${ }^{41}$

\section{Institutionalization of Sociology of Law \\ I. German Situation \\ 1. Universities}

Sociology of law became part of the curriculum for lawyers via the legal requirements for the training of lawyers, as set out in law. At this level, the curriculum is ultimately determined by political forces, and the inclusion of sociology of law thus did not need the consent of law schools. Germany's law on judges now required some knowledge of the social foundations of law. ${ }^{42}$ The provinces thus included aspects of sociology of law into the spectrum of topics potentially tested in the state bar exam, for example, today § 3(2) JAG Berlin, and § 7(1) JAG Hessen. ${ }^{43}$ The law schools had to organize lectures in sociology of law, and staff had to be employed to teach the subject. Yet most preferred a minimal solution. Given the politically controversial nature of sociology of law at the time and doubts over the concept of "sociological jurisprudence," law schools required candidates to be able to teach doctrinal law. Sociology of law became typically one of the several denominations of a chair, in combination with public, civil, or criminal law as a main working area. Professors had to have passed both Staatsexamen with an overall mark that

\footnotetext{
${ }^{33}$ Folsom \& Roberts, supra note 30, at 169.

${ }^{34}$ Pat Carlen, Introduction, in The Sociology of Law 1, 1 (Pat Carlen ed., 1976).

${ }^{35}$ See Id. The Society for Public Teachers of Law was "the then principal professional association of British university law teachers," according to David Sugarman, A Special Relationship? American Influences on English Legal Education, c. 1870-1965, 18 Int'L J. Legal Prof. 7, 19 (2011).

${ }^{36}$ Folsom \& Roberts, supra note 30, at 180.

${ }^{37} I$. at $174-75$, 177; Sugarman, supra note 35.

${ }^{38}$ Travers, supra note 26.

${ }^{39} \mathrm{Id}$.

${ }^{40}$ Michael King, Roger Cotterrell and Law's Sociology of Law, 42 J.L. Soc'Y 649, 649 (2015).

${ }^{41}$ Travers, supra note 26.

${ }^{42} \S 5 \mathrm{a}(2)$ Deutsches Richtergetz [The German Judiciary Act], Apr. 19, 1972, BGBL. I at 713 (Ger.), available at http://www. gesetze-im-internet.de/drig/BJNR016650961.html\#BJNR016650961BJNG000100666.

${ }^{43}$ Gesetz über die Ausbildung von Juristinnen und Juristen im Land Berlin (Berliner Juristenausbildungsgesetz - JAG), June 23, 2003, GVBL., 232 (Ger.), available at http://www.lexsoft.de/cgi-bin/lexsoft/justizportal_nrw.cgi?xid=216050,1; Gesetz über die juristische Ausbildung (Juristenausbildungsgesetz - JAG), Apr. 1, 2004, GVBL. I at 158 (Ger.), available at http://www. lexsoft.de/cgi-bin/lexsoft/justizportal_nrw.cgi?xid=169594,1.
} 
allowed them to become a judge. Furthermore, it was advisable to have published a significant amount of traditional legal books and articles. This constellation allowed universities to exclude sociologists on the one hand and to keep out left-leaning candidates on the other hand. ${ }^{44}$ In other words, sociology of law was only a side-aspect of a professor's duties. ${ }^{45}$ Any engagement with the subject beyond giving lectures and occasional seminars was an issue of personal preference. Therefore, the quality and extent of socio-legal research in Germany has suffered tremendously. ${ }^{46}$

Sociology, as the other parent discipline, might have offered more to sociologists of law, but in fact, it offered much less. The professionalization model of sociology in this period emphasized embedding sociology in other disciplines. ${ }^{47}$ And law faculties were reluctant to create chairs in sociology of law. Sociology had largely forgotten about law as a topic of research and teaching. ${ }^{48}$ In spite of the prominence of law within the oeuvres of, for example, Niklas Luhmann and Jürgen Habermas, ${ }^{49}$ German sociologists did not typically engage with it to any real extent.

There was a big chance for sociology of law to become an integrated part of legal education but it passed quickly. German legal education is traditionally divided into three years at university followed by a legal apprenticeship. Some German Länder in the 1970s introduced a one-phase model, the "einstufige Juristenausbildung," integrating practical training elements with academic studies. Furthermore, they also combined traditional legal learnings and the sociology of law. In this model, law students learned about the black-letter law in its application to legal problems, the legal practice in the application of law, and sociological analyses of the problem's social background. But after a few years, these experiments were abruptly stopped by political decision, because the framework for legal training is determined on the federal level where the opponents, who were chiefly from the politically more conservative southern Länder, were in the majority. Which model prepared lawyers better for their professional practice will never be known.

From this point onwards, the numbers of sociologists of law in permanent employment at universities started to dwindle. When a job was vacated, the law faculties allocated the positions to other legal subjects. Many members of the younger generation took up different careers or moved to the USA, the UK, Australia, or Norway, which offered more to sociologists of law.

Law students changed, too. Reforms, which aimed at streamlining and accelerating the speed of studies, resulted in students at universities concentrating all their efforts on passing the key assessments in doctrinal law. For their first state exam, most paid to attend extra lectures by private Repetitoren. A leaflet illustrates the clever marketing of a leading private Repetitor.$^{50}$ It shows three gladly laughing young males and lists their names. One of them pats the right shoulder of the man in the middle, the other one resting his arm on the left shoulder. The heading reads "Wir haben etwas 'gut' gemacht" ("We did something well"), playing with the word "gut" ("good" or "well", in English) which in this context means the three young men depicted made the right choice to go to this instructor, but more importantly, that they got an upper-level second class degree in the famously selective state exams. With this average, a career as a judge, public prosecutor, or at a reputable law firm was in sight, and the three are introduced to the reader as doctoral candidates. The Repetitors' formula was to calm nervous students down by offering them the bare bones of

\footnotetext{
${ }^{44}$ Pierre Guibentif, Niklas Luhmann und die Rechtssoziologie: Gespräch mit Niklas Luhmann, Bielefeld, den 7. Januar 1991, 21 ZFRSOZ 217, 230 (2000).

${ }^{45}$ Stefan Machura, Rechtssoziologie in der Juristenausbildung, 37 JURISTISCHE SCHULUNG 953 (1997); Barbara Heitzmann, Lehre der Rechtssoziologie an deutschen Hochschulen, 25 ZFRSOZ, 249 (2003); Wrase, supra, note 1; Hanna Uebach \& Sebastian Leuschner, Zum Stand der rechtssoziologischen Lehre und Forschung im deutschsprachigen Raum, 31 ZFRSOZ 303 (2010).

${ }^{46}$ Susanne Karstedt, Standortprobleme: Kriminalsoziologie in Deutschland, 23 SozIOLOGISCHE Revue 141 (2000).

${ }^{47}$ Bora et al., supra note 6 , at 320 .

${ }^{48}$ Bernhard Schäfers, Rechtssoziologie, in EINführung In SPEZIELle Soziologien 191, 195 (Helmut Korte \& Bernhard Schäfers eds., 1993).

${ }^{49}$ Niklas Luhmann, A Sociological Theory of Law (Martin Albrow ed., Routledge and Kegan Paul, 2d ed., 1985); Niklas luhmann, Das Recht der Gesellschaft (1993); Jürgen Habermas, Faktizität und Geltung (1993).

${ }^{50}$ Alpmann Schmidt, Wir haben was "gut" gemacht (1999) (on file with the author).
} 
doctrinal law. Sociology-related content did not figure at all as it was no secret that sociology of law was rarely asked for in the state exams.

After unification in 1990, the East German law faculties adopted the model of the west. As a consequence, law professors who were experts to the western system were in high demand. This allowed socio-legal scholars who had faced bleak job prospects after the end of the one-phase model of legal training to receive professorships at universities like Halle, Frankfurt-on-Oder, and Humboldt Universität Berlin. The result was a boost to socio-legal research, teaching, publication, and to the activities of sociology of law associations.

Another possible casing for sociology of law was research centers. One such attempt failed in Hamburg when the directors decided to disband the sociology of law research group. ${ }^{51}$ The years of Erhard Blankenburg's leadership of a sociology of law working group at the Wissenschaftszentrum Berlin have been described by Ralf Rogowski as the most productive for German sociology of law. ${ }^{52}$ Much later, the Law and Society Institute at the Humboldt University was founded. It successfully tapped into the well of talent available in the Berlin region and into the funding opportunities of the capital city. The "Recht als Kultur" Institute in Bonn is also a more recent development and has gained an international profile by hosting guest scholars.

\section{Associations}

The institutionalization of an academic subject also requires scholarly associations. The sociology of law section in the German Sociological Association (DGS) has been in existence since 1972. Wolfgang Kaupen, who made a name through empirical research on knowledge and opinion on law, was a key force in the early years. ${ }^{53}$ A second association, the Vereinigung für Rechtssoziologie, was founded in 1976 for several reasons. There were differences in appearance and motivations between professors of law and often younger sociologists energized by the student movement. ${ }^{54}$ Other reasons included that teachers of sociology of law in law departments needed a place to develop their common interests. Erhard Blankenburg, a key scholar, had a two-track strategy for the advancement of sociology of law in mind: The DGS section to continue its work, and the Vereinigung as a market-place where sociologists of law interested in empirical research set out their stalls. The strategy was successful in the following years. The Federal Justice Ministry tasked sociologists with a series of research projects. In this, Dieter Strempel, head of the ministry's unit for empirical legal research, was pivotal. ${ }^{55}$ As for the cultural clash, this aspect was soon ameliorated. By the 1990s, both German sociology of law associations worked together in a spirit of cooperation. Some scholars, including the author, sat on the committees of both. In 2010, the Vereinigung changed its name to "Vereinigung für Recht und Gesellschaft" ("Law and Society Association") following the example of the broad approach taken by the United States' Law and Society Association. Also notable is the Berliner Arbeitskreis Rechtswirklichkeit ("Berlin Working Group on Socio-Legal Studies"), which has a local focus but has, since its inception in 2001, developed a network that includes scholars throughout and beyond the borders of Germany.

\footnotetext{
${ }^{51}$ Dieter Martiny, Entstehung, Tätigkeit und Perspektiven der Sozialwissenschaftlichen Forschungsgruppe, in EMPIRISCHE Rechtsforschung ZWischen Wissenschaft und Politik 19, 25 (Konstanze Plett \& Klaus A. Ziegert eds., 1982). The research group existed between 1975 and 1982.

${ }^{52}$ Ralf Rogowski, Nachruf auf Erhard Blankenburg (1938-2018), 38 ZFRSOZ 168, 170 (2018).

${ }^{53}$ Rasehorn, supra note 13 , at 30.

${ }^{54}$ For the UK, see Campbell \& Wiles, supra note 28, at 568, 572. Life-style differences were also observed elsewhere as a factor of group delineation. See Nicholas Mullins, The Development of a Scientific Specialty: The Phage Group and the Origins of Molecular Biology, 10 Minerva 51, 72-73 (1972).

${ }^{55} \mathrm{His}$ stance can be gained from Dieter Strempel, Rechtstatsachenforschung und Rechtspolitik: Ressortforschung braucht den Dialog zwischen Wissenschaft und Politik, in EMPIRISCHE RECHTSFORSCHUNG ZWISCHEN WISSENSCHAFT UND POLITIK 113 (Konstanze Plett \& Klaus A. Ziegert eds., 1984).
} 


\section{Publications}

The teaching of an academic subject at universities needs an agreed-upon core of content. A model curriculum for the sociology of law ${ }^{56}$ was developed in 1975 by a working group dominated by lawyers because the subject was mainly taught at law schools. Introduction books were a further requirement for teaching purposes. Also, in the 1970s, four law professors in particular shaped the content of the sociology of law as a subject for law students by publishing introductory books, each with a different approach. ${ }^{57}$ The most all-encompassing presentation was drafted by Klaus F. Röhl, which widened the focus on German sociology of law to the broadest review of international approaches and empirical findings of sociological or other origins. ${ }^{58}$ The publication of introductory materials continued. ${ }^{59}$ Susanne Baer adopted a broader law and society approach but kept the familiar label sociology of law. Several book series feature sociology of law, including a dedicated series "Schriften der Vereinigung für Rechtssoziologie" (today "Recht und Gesellschaft") by the Association for Law and Society and a bilingual, German-English series "Society and Law" by Röhl and Machura. There was an annual publication, "Jahrbuch für Rechtssoziologie und Rechtstheorie" which now is a book series titled "Interdisziplinäre Studien zu Recht und Staat."

Generally, academic disciplines tend to have their own specialized journals. Since 1980, the "Zeitschrift für Rechtssoziologie," today with the subtitle "The German Journal of Law and Society," fulfils this role. Erhard Blankenburg was its "spiritus rector" in the early years. ${ }^{60}$ The ZfRSoz was preceded by an information letter that had the form and content of an academic journal: "Informationsbrief für Rechtssoziologie," edited by Wolfgang Kaupen. Articles in the ZfRSoz appear in both German and English, and there is a cooperation agreement with the French sister journal "Droit et sociéte" to exchange articles.

While some preconditions for the flourishing of German sociology of law are in place, it crucially lacks firm roots in the law schools and even more in sociology departments. Very few of its scholars enjoy permanent employment in positions allowing them to concentrate sufficiently on the subject. This is the main obstacle.

\section{UK Situation}

1. Universities

The UK Quality Assurance Agency has issued Benchmarks for the study of law, and while expressly giving faculties leeway, ${ }^{61}$ they state:

The study of law exposes students to a wide range of methods and techniques, some of which are specific to the discipline but some of which are drawn from the humanities and social sciences.... The common denominator is the requirement on the student to apply their understanding of legal principles, rules, doctrine, skills and values.

\footnotetext{
${ }^{56}$ Raiser, supra note 14 .

${ }^{57}$ Manfred Rehbinder, Einführung IN die Rechtssoziologie: Ein Textbuch für Studenten Der Rechtswissenschaft (1971); Thomas Raiser, Rechtssoziologie (1987); Röhl, Rechtssoziologie supra note 24; Helmut RotTleuthner, EinfÜHRUNG IN Die Rechtssoziologie (1987).

${ }^{58}$ RÖHL, RECHTSSOzIOlOGIE, supra note 24 . A revised version is available online at https://rechtssoziologie-online.de/. Klaus F. Röhl, Lehrbücher und Reader, REchTsSOZIOLOGIE-ONLINE.DE, §https://rechtssoziologie-online.de/kapitel-1/§-2fortsetzung/i-rechtssoziologie-in-lehrdarstellungen-und-readern/ (last accessed Aug 29, 2019) (listing German introductions).

${ }^{59}$ Erhard Blankenburg, Mobilisierung des Rechts: eine Einführung In Die Rechtssoziologie (1995); Gerhard Struck, Rechtssoziologie (2011); Susanne Baer, Rechtssoziologie (3d ed. 2017).

${ }^{60}$ Rogowski, supra note 52, at 170 .

${ }^{61}$ Quality Assurance Agency, Subject BenChmark Statement Law 4 (2019) https://www.qaa.ac.uk/docs/qaa/subjectbenchmark-statements/subject-benchmark-statement-law.pdf?sfvrsn=b939c881_18 (last visited 5 September 2020).
} 
Law students are required to evidence

... knowledge and understanding of theories, concepts, values, principles and rules of public and private laws within an institutional, social, national and global context. ${ }^{62}$

A survey published in 1983 showed that sociology of law and socio-legal studies had indeed become, although to varying degrees, part of university teaching in the UK. ${ }^{63}$ Sociology departments rarely featured sociology of law, however. ${ }^{64}$ Earlier, Hunt saw it leading "a somewhat precarious existence predominantly located on the fringes of law departments and faculties." 65 Roughly two decades later, Foster and Osborn, commenting on law as an academic discipline, stated "the socio-legal has become the dominant approach in the UK." ${ }^{66}$ This opinion is supported by several other scholars. Reading Cownie and Bradney's account, socio-legal studies are especially important when it comes to the research identity of legal scholars and research activity. ${ }^{67}$ Sugarman suggested that most scholars at law schools no longer restrict themselves and their teaching to black-letter law, but take social context into account. ${ }^{68}$ And Creutzfeldt summarizes the developments as "socio-legal scholarship is now an established focus of scholarly and institutional interest." 69 If this is indeed the situation, how did it transpire?

As is the case in Germany, the study of law in the UK has a two-stage structure. Three years of university, four in Scotland and Northern Ireland, are followed by traineeships, the latter of which, however, are organized differently from those in Germany. Some UK law faculties follow the "liberal model of legal education," where the technical study of legal skills is complemented by broader, cultural and social elements. ${ }^{70}$ To mention an example, at Cardiff University, where the author was an external examiner, law students find not only a module in jurisprudence, but also a sociology of law module. The latter comprises major theories as well as socio-legal topics of the day. Sociology of law elements are often included in jurisprudence textbooks and in courses on jurisprudence, while dedicated sociology of law programs have been reduced. ${ }^{71}$ Creutzfeldt explicitly mentions Bristol, Cardiff, Exeter, Glasgow, Kent, and Oxford as law schools offering socio-legal courses. ${ }^{72}$ In contrast, Warwick, for example, offers a BA Law with Social Sciences, which is similar to other universities like Bangor, which allows students to study law with social science subjects. LLM and MA specialist degrees like "Human Rights" have strong socio-legal content ${ }^{73}$ similar to many law and criminology MA degrees.

Law students, according to King, are preoccupied "with gaining as quickly as possible those qualifications which they believe will place them firmly on the rungs of a career ladder." 74 Yet, in defense of current student generations, it has to be said that much has changed since

\footnotetext{
${ }^{62} I d$. at 5 .

${ }^{63}$ Nigel Fielding \& Jane Fielding, Teaching the Sociology of Law: An Empirical Study, 10 J.L. Soc’y 181 (1983).

${ }^{64}$ Max Travers, Putting Sociology Back Into the Sociology of Law, 20 J.L. Soc'y 438, 442 (1993).

${ }^{65}$ Alan Hunt, The Sociological Movement in LaW 1-2 (1978).

${ }^{66}$ Foster \& Osborn, supra note 32, at 3.

${ }^{67}$ Fiona Cownie \& Anthony Bradney, Socio-Legal Studies, in ResearCh Methods IN LaW, 40 (D. Watkins \& M. Burton eds., 2 d ed. 2018).

${ }^{68}$ Sugarman, supra note 35 , at 29.

${ }^{69}$ Naomi Creutzfeldt, Traditions of Studying the Social and the Legal: A Short Introduction to the Institutional and Intellectual Development of Socio-Legal Studies, in Routledge Handbook of Socio Legal Theory and Methods, 9, 19 (Naomi Creutzfeldt, Marc Mason \& Kirsten McConnachie eds., 2019).

${ }^{70}$ Julian Webb, Education, Legal, in ENCYClOPEdia of LAW AND SOCIETY. AMERICAN ANd GlObal PerspeCtives 461,462 (David S. Clark ed., 2007).

${ }^{71}$ King, supra note 40, at 657.

${ }^{72}$ Creutzfeldt, supra note 69 , at 19.

${ }^{73}$ Bradney, supra note 29 , at 1532.

${ }^{74}$ King, supra note 40, at 657; Stephen Clear \& Marie Parker, A Model for Responding to UK and International Law Students' Great(er) Expectations in Wales' Internationalised Learning Environment, 13 J. COMMONWEALTH L. \& LEGAL EDUC. 62,71
} 
the 1970s when socio-legal studies were introduced. There is more doctrinal law to master, more competition for jobs in a forbidding climate for lawyers, and on top of it, UK students have to take out loans to cover substantial fees and living costs. Loan schemes have been introduced for postgraduate studies, allowing more students to extend their education to a postgraduate phase with more specialized master's studies. In these, doctrinal law is often mixed with socio-legal content.

Government-related funding - such as the ESRC and the Nuffield Foundation, a charitable organization-was instrumental in the development of socio-legal studies in the UK. Although, after initially good conditions, funding for socio-legal studies was drastically reduced in the 1980s and 1990s. ${ }^{75}$ Michael King observes rightfully that in the current climate, the "expectations and demands of legal academics and those who make grants to them and publish their books and articles all pull in the direction of an instrumental approach to social theory." 76 It is similar to research, which has to demonstrate an impact on society.

Historically, Max Travers noted there used to be class differences between lawyers and sociologists, which were roughly similar to German society, with the former belonging to a higher category, resulting in a cultural clash. ${ }^{77}$ This is probably no longer the case, as in Germany, professorial pay was in general significantly reduced, and in the UK, coinciding with the de facto privatization of universities, salaries of lecturers and professors slipped in real value, and many lecturers hold precarious employment contracts.

Few sociologists without a law degree are employed at British law faculties, with the notable exception of criminologists whose subject is based in law schools at some universities. In 2006, a commission tasked by the Nuffield Foundation claimed that there was not enough trained staff to conduct empirical research in socio-legal studies. ${ }^{78}$ The situation has improved in the intervening years, in part because of efforts by the ESRC. Nevertheless, in 2015 Sugarman wrote about "the general failing of legal education to provide even basic training in empirical and socio-legal research skills." In Germany, there was the opposite situation to the Nuffield Foundations' findings, and many well-trained German sociologists of law left the country. Some of them, for example, took up employment on the British Isles.

When it comes to British research institutes having a role in the history of sociology of law, the Oxford Centre for Socio-Legal Studies provided an example of how quickly winds can change for socio-legal studies. As Director, Donald Harris employed sociologists as researchers to collaborate with lawyers and sought to combine theoretical and empirical work. ${ }^{80}$ Government funding was cut in the early 1980s, and the new director was "no longer committed to recruiting sociologists to work alongside law school researchers." ${ }^{\prime 1}$ Luckily, things have changed again in the meantime.

\section{Associations}

The history of academic associations in the UK goes back, according to Campbell and Wiles, to discussion groups. Campbell and Wiles mention a "Socio-Legal Group," founded in 1971, which

(2019) (Mentioning as a representative UK student voice: “To gain a broad understanding of the skills needed to progress into the law profession").

${ }^{75}$ Linda Dickens, Some Notes on the English Experience, in EMPIRISCHE RECHTSFORSCHUNG ZWISCHEN WISSENSCHAFT UND Politik 185, 185 (Konstanze Plett \& Klaus A. Ziegert eds., 1984); Travers, supra note 26, at 36. Social sciences were not a priority for successive governments of the Conservative party at the time.

${ }^{76}$ King, supra note 40 , at 85 .

${ }^{77}$ Travers, supra note 26.

${ }^{78}$ Hilary Genn, Martin Partington \& Sally Wheeler, LaW in the Real World: Improving Our Understanding HOW LAW WORKS 45-46 (2006); Travers, supra note 26, at 36.

${ }^{79}$ David Sugarman, From Legal Biography to Legal Life Writing: Broadening Conceptions of Legal History and Socio-Legal Scholarship, 42 J.L. Soc'Y 7, 14 (2015).

${ }^{80}$ Mavis Maclean, Prize Acceptance, RCSL NewsLETTER 2/2019, 17 (2019), http://rcsl.iscte.pt/rcsl_nl_2019_2.pdf; Travers, supra note 26 , at 29,32 .

${ }^{81}$ Travers, supra note 26, at 29. 
then merged with "the smaller Law Group of the British Sociological Association." 82 Their membership, which boasted 250 academics and postgraduate students, ${ }^{83}$ was already impressive in comparison with German associations. The UK Socio-Legal Studies Association (SLSA) was established rather late by comparison in 1990, but its ranks swelled quickly, and it soon became the second largest academic association for lawyers in the UK. ${ }^{84}$ SLSA was characterized as "deliberately ecumenical socio-legal association," bridging different conceptions of the relation of sociology and law. ${ }^{85}$ The range of activities is much larger than that of its German counterparts. SLSA Annual Conferences occur more regularly than the Austrian-German-Swiss meetings. The SLSA membership compares favorably with the DGS section's eighty-seven, while the section's email list has 225 addresses, and the Vereinigung's 159, with its newsletter going out to 428 addresses. ${ }^{86}$ Most of the SLSA members are from law schools. ${ }^{87}$

\section{Publications}

What journals mark the establishment of the subject in the UK? The main UK outlet for the subject is the Journal of Law and Society. It started in 1974, six years earlier than the German ZfRSoz, as British Journal of Law and Society. Remarkably, now-Emeritus Professor Philip Thomas of the Cardiff School of Law and Politics has served as the journal's Editor in Chief since its establishment. His first editorial stated: "We do not subscribe to the view that the social scientist is to be cast in the role of handmaiden to the lawyer." 88 A slight preference for theoretical work can be read between the lines, but an openness for empirical articles was also expressed.

On its website, the journal Law and Critique, established in 1990, presents itself as "the prime international critical legal theory journal," ${ }^{99}$ appearing under the publisher's "Philosophy and Law" portfolio. Another publication, Social and Legal Studies, harking back to 1992, seeks to attract "progressive, interdisciplinary and critical approaches to socio-legal study." 90 Yet another outlet, the International Journal of the Sociology of Law, appears today under the title International Journal of Law, Crime and Justice, signaling a shift to criminology.

Outlining the history of socio-legal studies, Campbell and Wiles mention the Law and Society book series, ${ }^{91}$ while Folsom and Roberts additionally reference the series Law in Context and Modern Legal Studies. ${ }^{92}$ From the mid-nineties onwards, Richard Hart printed many socio-legal books, and publication continues today as part of Bloomsbury. At present, there is an emphasis on articles in international peer-reviewed journals and open access, which further challenges conventional publication patterns. Open access is a requirement for the Research Excellence Framework (REF), the cyclical evaluation of university research that triggers government funding. But demand for open access is also driven by authors wishing to better disseminate their work.

\footnotetext{
${ }^{82}$ Campbell \& Wiles, supra note 28 , at 568.

${ }^{83} I d$.

${ }^{84}$ Anthony Bradney, Socio-Legal Studies Association, in EnCyClopedia of LAW AND Society. AmERICAN AND GlObaL Perspectives 1408, 1408 (David S. Clark ed., 2007).

${ }^{85}$ David Nelken, Blinding Insights? The Limits of a Reflexive Sociology of Law, 25 J.L. Soc'y 407, 408 (1998).

${ }^{86}$ The current list of SLSA members has about 1,300 addresses, according to Jen Hendry, Associate Professor in Law \& Social Justice, University of Leeds (Sept. 13, 2019, 13:38 CET) (on file with the author), but is reported to be inaccurate, with the number of paying full members rather being in the region of 500. For the membership of the German association: Email from Andrea Balog-Hiatt, Secretary, Vereinigung für Recht und Gesellschaft (Aug. 27, 2019, 08:24 CET) (on file with the author); Emails from Doris Schweitzer, Speaker Sektion Rechtssoziologie (Sept. 4 and 10, 2019, 12:33 and 13:02 CET) (on file with the author). It is important to note that many individuals will be in both German organizations.

${ }^{87} \mathrm{~A}$ fact already reported in Bradney, supra note 29.

${ }^{88}$ British Journal of Law and Society, Editorial, 1 BRITISH J.L. SOC'Y 1, 1 (1974).

${ }^{89}$ Law and Critique, https://www.springer.com/philosophy/philosophy+of+law/journal/10978 (last visited Jan. 15, 2019).

${ }^{90}$ Socio \& Legal Studies, Aims and Scope, https://uk.sagepub.com/en-gb/eur/journal/social-legal-studies\#aims-and-scope (last visited Aug. 25, 2019).

${ }^{91}$ Campbell \& Wiles, supra note 28, at 568, 572.

${ }^{92}$ Folsom \& Roberts, supra note 30, at 173-74, 189.
} 
In the UK, there is not the same range of books for beginners as in Germany. Roger Cotterrell's The Sociology of Law: An Introduction stood largely alone in the UK. ${ }^{93}$ Travers characterized it as reflecting the legal theorist's "instrumental, and, in some respects, unashamedly eclectic interest in sociology as an academic discipline," an interest directed at power relations in society. ${ }^{94}$

Socio-legal studies in the UK has a much larger footprint than its counterpart in Germany. It owes its better position in part to the broader definition compared to Rechtssoziologie and also to the greater openness of UK law schools for ideas from other disciplines and inter- and transdisciplinary endeavors.

\section{Conclusion}

The development of the subject in the UK and Germany shows some initial similarities, but also significant differences. The mobilization phase in Germany was long and drawn out, interrupted for some decades, and mainly characterized by particular scholars. By comparison, in the UK, the mobilization phase was shorter, but with key scholars and government action. In both countries, its inclusion in university curriculums was more successful in law schools than in social sciences. In Germany, inclusion finds its main expression in sociology of law lectures, while in the UK, socio-legal studies are reflected across a multitude of modules. As a consequence, specialized introductory books are more of a feature in Germany. Again, in both countries, lecturers are mainly employed in law schools, and there is a preference for legally qualified staff. In Germany, the state dominates legal education to a higher degree than in the UK. This is a result of the state exams which define the professional careers of German law students. UK law faculties are influenced by the rigidities of regular research evaluation exercises. The first results in orienting studies towards black-letter law and towards the decisions of higher courts, while the second points towards what stakeholders in the legal system regard as beneficial. Another consequence of the dispersed nature of education in socio-legal studies in the UK is that the Socio-Legal Studies Association attracts more scholars, and postgraduates, than its German counterparts, allowing for a wider range of activities. In both countries, there are a plethora of publication outlets: In Germany, there is a greater concentration on one journal.

German sociology of law started earlier, but by the end of the 1970s, it had encountered strong opposition, which arguably continues today. UK socio-legal studies is more of a success story, although the core sociology of law element-as defined by Blankenburg's insistence on sociological theories and social science methods - was, and still is, the minority. Political motivations were prominent, especially in Germany. They have boosted the development of socio-legal studies and sociology of law, but because of their divisive character have also harmed the prospect of being recognized in all quarters.

Clearly, sociology of law has not yet realized its full potential in Germany. The past suggests that further developments in both countries depend on a number of factors. Funding support for research will be important to broaden the range of findings, keeping pace with the developments in society and its laws. The subject has to be represented in the universities' curriculums, and more students must become interested in studying it. An infrastructure of academic associations and publication outlets is needed to attract scholars and bring different approaches together. To keep scholars engaged with the subject, permanent positions in teaching and research are key to allow them to concentrate on the field. In addition, dedicated research institutes can further strengthen socio-legal studies and sociology of law. They allow for addressing problems that do not find enough sustained attention in universities.

\footnotetext{
${ }^{93}$ Roger Cotterrell, The Sociology of Law: An Introduction (2d ed. 1999).

${ }^{94}$ Travers, supra note 26 , at 445.
} 
In the end, however, many people are focusing on social problems created by law, legal problems to be approached by social research, or theoretical endeavors driven by a disciplinary or transdisciplinary approach that they may gain from each other's work.

A final consideration: To have lasting careers in academia, scholars in both countries need a strong disciplinary identity. It requires full credentials as typically a sociologist or lawyer. In the German case, the two disciplines are miles apart. There still is a deep rift between what is essentially an empirically oriented sociology working with theoretical tools that principally apply everywhere, and jurisprudence that is still mostly concentrating on norms formulated to guide the application of state law. The UK example shows that the two disciplines can meet, no doubt. But at present, they do so more often in the UK than in Germany. 